Proc $2^{\text {nd }}$ APCRS

\title{
Fish aggregating devices in Indonesia: Past and present status on sustainable capture fisheries
}

\author{
Roza YUSFIANDAYANI ${ }^{1, *}$ \\ ${ }^{1}$ Department of Fisheries Resources Utilization, Bogor Agricultural University, Indonesia \\ * Corresponding author: R. Yusfiandayani \\ E-mail: ocha_roza@yahoo.com
}

\begin{abstract}
The use of rumpon, a type of Fish Aggregating Device (FAD), has been traditional in Indonesia, particularly in eastern Indonesia waters since long time ago (Reuter 1938; Nasution et al. 1986; Monintja 1976). The traditional tuna fishermen in Mamuju waters in the Province of South Celebes have used rumpons for a long time, although there is no record when the device was first used (Nasution et al. 1986). There are a variety of structures designed or made to attract free schooling fishes: rumpon (Indonesia), correct space tendak (West Java), uncang (Sumatera), rompong (Sulawesi), payaos (Philippines). Local fishermen claimed that they learned how to construct the rumpon from their ancestors, but did not apply the device extensively until 1985 because of the low profitability of catching the swift swimming fishes. The use of rumpon for fishing activities has improved the effectiveness and efficiency if compared with other fishing gear. However, the fast increasing of rumpon utilization has raised a great concern on the sustainability of the fish resources. The rumpon management for a responsible fisheries policy should consider aspects of biology, location, environment, fishing techniques, social and economic. The existing condition of rumpon has been not fully understood and its usage in a responsible manner require further elaboration. Therefore, the information of the past and present situation of rumpon in Indonesia will be important for further management.
\end{abstract}

The main data were collected and compiled from various references, annual report of the Directorate General of
Fisheries and research report of Central Research Institute for Fisheries. Additional data were obtained from local fisheries agencies or related institutions.

Structure of the rumpon installed in the Provinces of North Sumatera, West Sumatra, Lampung, West Java, East Java, North Celebes, Central Celebes, South Celebes, Maluku Islands and Papua are given in detail. There are 2 types of rumpon: the deep sea rumpon and shallow water rumpon. Differences among the rumpons in those areas are mostly found in the material of the mooring line, shape and material of the float and the structure of attracting components. The mooring line is mostly made of polyethylene of 12-25 $\mathrm{mm}$ in diameter or nylon of 5-10 $\mathrm{mm}$ in diameter. There are wide variations of shape of floats. Generally they are divided into pontoon type or box shape made of steel and raft type made of bamboos. Attractors are made of coconut leaves, nipah leaves and pine leaves. Some attractors are attached to the mooring line and the others are hung down from the float. They are operated a wide range of water depth from 20 to $1500 \mathrm{~m}$. The fishing ground conditions, bottom topography and bottom configuration are among the factors considered for the rumpon design and construction. The differences in construction are mainly due to the rumpon location, target species in each area and the fishing gear applied.

Keywords fish aggregating device, rumpon, sustainable fisheries, Indonesia 


\section{Introduction}

The use of rumpon, a type of Fish Aggregating Device (FAD), is traditional to Indonesia, particularly in eastern Indonesia waters since time immemorial (Reuter 1938; Nasution et al. 1986; Monintja 1976). The traditional tuna fishermen in Mamuju waters in the Province of South Celebes have used rumpons for a long time, although there is no record when the device was first used (Nasution et al. 1986). There are several structures designed or made to attract free schooling fishes: rumpon (Indonesia), tendak (West Java), uncang (Sumatera), rompong (Sulawesi), payaos (Philippines). Local fishermen claimed that they learned how to construct the rumpon from their ancestors, but did not apply the device extensively until 1985 because of the low profitability of catching the swift swimming fishes.

Some pelagic fishes have habit to be easily attracted and gather around a floating object in the open ocean (Gooding and Magnuson 1967). Inoue et al. (1968) noted that tunas and skipjack frequently gather around a drifting object (wood) in the open ocean. However, Scott (1969) observed that the associated schools of tuna could be divided into two groups. First, those associated with other animals, such as with porpoises, whales, sharks and the second one are those associated with inanimate objects, such as floating object, log, flotsam etc. Therefore, fishermen usually take advantage of these behaviors for fishing pelagic fishes.

Those knowledges are used as a basis of the usage of FAD for pelagic fishery enhancement. Several researchers have been interested in studying the association of pelagic fish with floating object in the sea. Greenblatt (1979) and Inoue et al. (1968) observed the association of tunas and skipjack with flotsam and drift wood in the Pacific Ocean. Hunter and Mitchell (1968) evaluated the different surface FADs configuration for the attraction of pelagic fish. Study of midwater FADs for attracting commercially and recreationally pelagic fishes has also been studied (Wickham et al. 1973; Wickman and Russell, 1974). Firstly, FADs were commonly used in the coastal water areas with water depth of less than a hundred meters and for attracting small pelagic fishes. However, in the recent years these devices were deployed in the open ocean with water depth of more than a thousand meters and not only for catching small pelagic fishes but also larger pelagic fishes such as tuna, dolphin fish, skipjack and marlins.

Intensive study on deep sea rumpon for skipjack tuna fisheries in Indonesia was started in 1976. The Marine Fisheries Research Institute conducted the field experiments and fishing industrial sector since 1980 and the commercial operations was successful in 1985. Rumpons affect skipjack and yellowfin catchability and abundance. However it may also make the stocks more susceptible to overfishing (Mathews and Monintja 1996). Effects of rumpon on tuna fishing must be taken into account when addressing some of the concerns being raised about the coastal and offshore tuna fisheries in the Sulawesi Sea and elsewhere in Indonesian waters.

In Indonesia, fishermen are using floating materials to aggregate pelagic species including tuna, mackerel, scads, sardines, etc. The man made floating devices are called rumpon, and widely employed by artisanal fishermen in the northern Java Sea and southern Celebes Sea. However, Rumpons used are quite different. Fishermen in Java construct their rumpon using coconut leaves and bamboo stems to catch small pelagic fishes, while the FAD used in southern Celebes Sea aimed tuna and related fishes, and are originally made of bamboo raft with rattan mooring line. The traditional rumpon usually lasts only in short period of time of two month or less.

The fast growing of rumpon utilization has raised a great concern on the sustainability of the fish resources. The rumpon management for responsible fisheries should consider aspects of biology, location, environment, fishing gear, social and economics. The existing condition of rumpon has been not fully understood and its usage in a responsible manner also needs

further consideration. For that purpose, information of the present situation and the impact of rumpon in Indonesia will be important for further development in the near future.

\section{Materials and methods}

Data and information were collected and compiled 
from various references, international proceedings, reports of the Ministry of Marine Affairs and Fishery, Marine Fisheries Research Center, local fisheries agencies and related institutions.

\section{Results and discussion}

There are two types of FADs or rumpon in Indonesia: the deep sea rumpon and the shallow water rumpon. The deep sea rumpon for tuna have been utilized in tuna fishing ground in eight provinces inclusive of North Sumatra, West Sumatra, Lampung, West Java, East Java, North Celebes, Central Celebes, South Celebes, Maluku and Papua (Monintja, 1993). The shallow water rumpon have been utilized in Lampung and Banten (Yusfiandayani, 2004).

As similar to the FAD's utilized in other countries, the construction of rumpon in Indonesia basically consists of four main components, namely the buoy or float, the attractor, the mooring line and the sinker. A detail structure of the deep sea rumpon in Gorontalo is shown at Figure 1. The Mamuju type of rumpon used in the Province of South Celebes is composed of bamboo raft as float, coconut leaves as the attractor (Table 1). The mooring line is composed by rattan string combined with polyethylene ropes. Fishermen are using mountain stones fixed by rattan string at the end of mooring line as the sinker (Fig. 1). The Central Celebes type of rumpon is composed of bamboo raft as float and a pontoon as the attractor (Table
2). The sinker comprises of two oil drums (filled with concrete cement) and an anchor. Rattan webbing is installed to protect the PE rope from abrasion (Fig. 2).

Up to 1987 a total of 11 units of rumpon had been tested in West Sumatra waters. The first three units were designed by the Marine Fisheries Research, while the rest of eight units were designed and deployed by PT. Usaha Mina. The details of components are presented in Table 3. The rumpons deployed in the Gulf of Pelabuhan Ratu, West Java, had the structure of two layers raft type float and additional buoy of oil drum filled with polyethylene. The

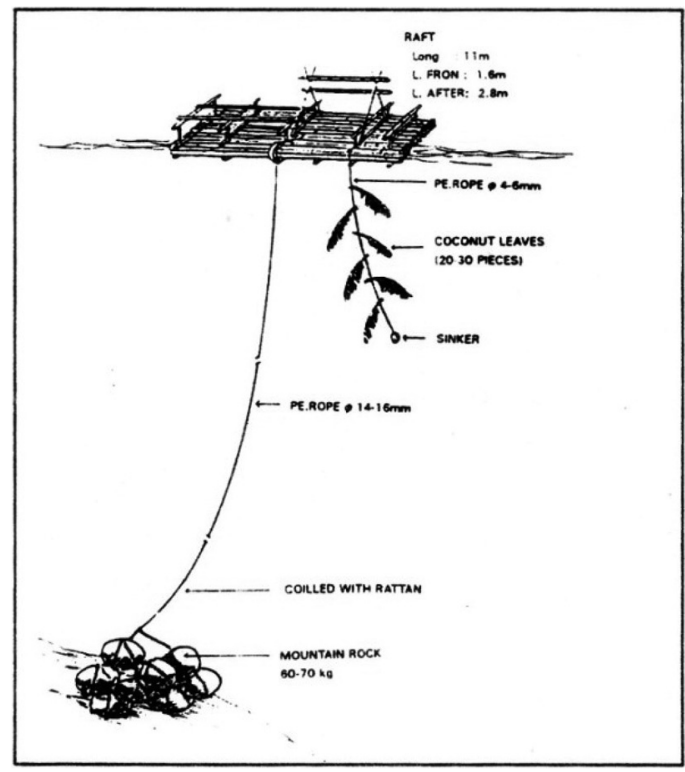

Fig. 1 Deep sea rumpon in Mamuju (South Celebes Province Fisheries Agency 1987)

Table 1 Material and size of deep sea rumpon in Mamuju

\begin{tabular}{|c|c|c|c|c|}
\hline No. & Component & Material & Size & Amount \\
\hline \multirow[t]{6}{*}{1.} & Tuna rumpon buoy & & & \\
\hline & Raft & Bamboo & $\mathrm{L}=11 \mathrm{~m}$ & $80-120$ bar \\
\hline & Wooden bar & Wooden bar & $\mathrm{D}=1.6-2.6 \mathrm{~m}$ & - \\
\hline & Pajala/romping & & $\mathrm{L}=12 \mathrm{~m}, \mathrm{D}=8 \mathrm{~cm}$ & - \\
\hline & Main and addition & Bamboo & $\mathrm{L}=9 \mathrm{~m}$ & $80-100$ bar \\
\hline & Raft & & $\mathrm{B}=1.6-1.8 \mathrm{~m}$ & - \\
\hline \multirow[t]{4}{*}{2.} & Attractor & & & \\
\hline & Appendages & Coconut leaves & & $20-30$ sheet \\
\hline & Rope & Polyethylene & $\Phi=4-6 \mathrm{~mm}$ & - \\
\hline & Pajala & & $\mathrm{L}=30-50 \mathrm{~m}$ & - \\
\hline 3. & Mooring line pajala & & $\begin{array}{l}\Phi=14-16 \mathrm{~mm} \\
\Phi=8-10 \mathrm{~m}\end{array}$ & $\begin{array}{l}4-10 \text { coil } \\
5,000 \text { bar }\end{array}$ \\
\hline 4. & Sinker & Stone & & $60-70$ piece \\
\hline
\end{tabular}

Source : Nasution et al. 1986 
Table 2 Material and size of deep sea rumpon in Mamuju

\begin{tabular}{lllll}
\hline No. & Component & Material & Size & Amount \\
\hline 1. & Buoy & & & \\
& Raft & Bamboo & $\Phi=16 \mathrm{~m}$ & 16 bar \\
& Pontoon & Wooden bar & $\mathrm{D}=0.3 \mathrm{~m}$, & - \\
& & $\mathrm{L}=3 \mathrm{~m}$, & $\mathrm{B}=0.3 \mathrm{~cm}$ & - \\
2. & Appendages & Coconut leaves & - & 6 coil \\
3. & Mooring line & Polyethylene & $\Phi=4-6 \mathrm{~mm}$ & 1 pc \\
& $\begin{array}{l}\text { Rope } \\
\text { Swivel }\end{array}$ & & $\Phi=5 / 8$ inch & 2 units \\
Bottom sinker & Sinker & Concrete cement + iron bar & - & 1 unit \\
\hline
\end{tabular}

Source : Gorontalo Municipality Fisheries Agency 1990

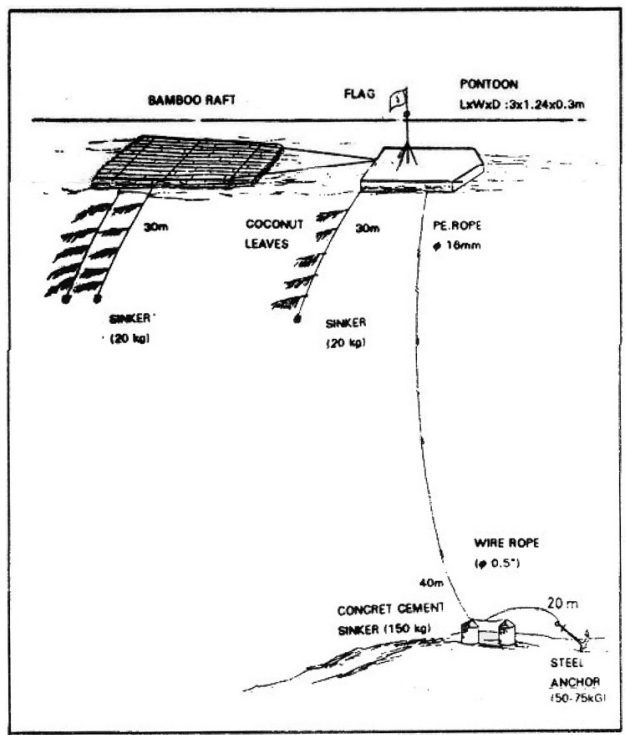

Fig. 2 Deep sea rumpon in Gorontalo (Gorontalo Municipality Fisheries Agency 1990)

mooring line construction was similar to the PT. Usaha Mina type, with a minor modification in the material and sizes of the components (Table 4). Figure 3 showed the structure of deep sea rumpon in West Java.

The Banten type of rumpon in Sunda Strait as shallow water rumpon, had the same material of the components of deep sea rumpon (Table 5). The Lampung types in Teluk Belebuh Bay had the same component with the Banten rumpon. The depth of the shallow water rumpon was $20 \mathrm{~m}$ (Fig. 4).

In order to use deep sea FAD in the Indonesia waters license must be obtained from the Directorate of Capture Fisheries, Ministry of Marine Affairs and Fisheries Re- public of Indonesia. Required document for license must describe the design of deep sea FAD, rumpon ownership, location of deployment of deep sea FAD. Documento must be sent to the Directorate of Capture Fisheries, Ministry of Marine Affairs and Fisheries Republic of Indonesia. The documents will be studied and proposed in the survey. After studied and surveyed the license will be given to the owner of deep sea FAD.

The number of licensed deep sea and shallow water rumpon in Indonesia for the period of 2006-2008 is shown in Figure 5. The highest are 41 units in South Celebes and the lowest in Ceram Sea with 4 units. A comparison between number of deep sea and shallow water rumpon in Indonesia is shown in Figure 6. The numbers of deep sea rumpon are 54 units, and the shallow water rumpon are 39 units.

Several researches conducted on the impact of FAD on fisheries showed positive results:

(1) In Indonesia (Monintja and Mathews 2000)

$>$ Eastern Indonesia skipijack fisheries, pole and line

$>$ Increased in CPUE 41\%

$>$ Landing's of fish per ton of live bait increased $24 \%$

$>$ Reducing diesel oil consumption: $46 \%$

$>$ Increasing profit: 10 to 60 million rupiah per boat

$>$ Increasing catch ability $40 \%$

(2) In the Pacific Ocean (Sakagawa GT 2000)

$>$ Rate of success fishing $96 \%$

$>$ High yield rate (37 ton/set)

FAD improved the fleet performance

(3) In Solomon Island (Sibiospere 2000) 
Table 3 Material and size of deep sea rumpon in West Sumatra

\begin{tabular}{|c|c|c|c|c|}
\hline No. & Component & Material & Size & Amount \\
\hline \multirow[t]{2}{*}{1.} & \multirow[t]{2}{*}{ Buoy } & Bamboo & $\begin{array}{l}\Phi=16 \mathrm{~m} \\
\mathrm{~L}=9 \mathrm{~m}\end{array}$ & 38 bar \\
\hline & & Fibre glass & $\begin{array}{l}\Phi=1 \mathrm{~m} \\
\mathrm{D}=6 \mathrm{~m}\end{array}$ & 1 unit \\
\hline 2. & Attractor & Coconut leaves & - & 225 sheet \\
\hline \multirow[t]{4}{*}{3.} & \multirow[t]{4}{*}{ Mooring line } & Wire rope & $\begin{array}{l}\Phi=16 \mathrm{~mm} \\
\mathrm{~L}=6 \mathrm{~m}\end{array}$ & - \\
\hline & & Polyethylene & $\begin{array}{l}\Phi=18 \mathrm{~mm} \\
\mathrm{~L}=50 \mathrm{~m}\end{array}$ & - \\
\hline & & Wire rope & $\begin{array}{l}\Phi=16 \mathrm{~mm} \\
\mathrm{~L}=30 \mathrm{~m}\end{array}$ & - \\
\hline & & Polyethylene & $\Phi=22 \mathrm{~mm}$ & - \\
\hline 4. & Bottom sinker & $\begin{array}{l}\text { Concrete cement + iron bar } \\
\text { Mountain's stone }\end{array}$ & $\begin{array}{l}200 \mathrm{lt} \text { of drum oil } \\
6-8 \mathrm{~kg} / \mathrm{pc}\end{array}$ & $\begin{array}{l}1 \text { unit } \\
200 \mathrm{pc}\end{array}$ \\
\hline
\end{tabular}

Source : Padang Municipality Fisheries Agency 1988

$>$ The FAD Utilization has increased the total yield of skipjack tuna in Solomon Islands

$>$ Saving in operational cost

$>$ Reducing fishing searching time

$>$ Better regularity of landings

(4) In CapeVerde (Helene Rey-Valette, Pericles Martin 2000)

$>$ The FAD has stabilized the fishing activities in Cape Verde Islands

(5) In Central Western Pacific Ocean (Coan and Bartoo 2000)

$>$ FAD catches increased from $2000 \mathrm{mt}$ (1995) to $64000 \mathrm{mt}$ (1996)

$>$ FAD catch per set remained high

$>$ Bigeye tuna catches increased 3 fold

(6) In Malaysia (Rumpet 2000)

FAD has proven to enhance the catch of pelagic fish

Negative impact of FAD on the fisheries were also reported:

(1) In Indonesia (Mathews et al. 1996)

$>$ Development of industrial tuna purse seiners equipped with FAD from Philippnes had caused decline in CPUE, of the Tomini Gulf fisheries.

(2) In Indonesia (Mathew et al. 1996)

$>$ The introduction of Philippine rumpon into Indonesia EEZ- and territorial waters has reduced the CPUE of the local skipjack fisheries to $23 \%$.

$>$ The CPUE of yellowfin tuna in Manado and
Bitung declined after the introduction of rumpon in 1990.

(3) Worldwide review (Fonteneau, Pallares, Pianet 2000)

$>$ The use of FADs needs to be controlled and limited to sustainable biological levels.

(4) In Indonesia (Yusfiandayani 2004)

$>$ Most of the small pelagic fish (72\%) caught around FAD in Pasauran waters are immature fish.

International issues on the impact of FAD have been brought up since 1999 in the International Symposium on Tuna Fisheries and Fish Aggregating Device in Martinique, France. The issues included the fast growing of FAD utilization in the Eastern Pasific Ocean, as the drifting aggregating devices, were reported catching the small size and immature fishes debate on the pros and cons of FAD application on fisheries continues, since the gear is categorized as non selective fishing gear. In Indonesia, several policies and management measures have been officially assigned by the government, such as the ministry's regulation No. 51/Kpts/IK.250/1/97 and ministry's regulation No. 30/Men/2004 on the deployment and utilization, and the decision of Director General of Capture Fisheries No. 4179/ DPT.2/PI.340.D2/IX/08 on the prohibition of using rubber type of rumpon. The ministry regulation discussed about FAD deployment zones, FAD deployment licensing, FAD marking and FAD operation reporting.

Hilborn and Medley (1989) proposed the model for the analysis of fishing tuna from FAD. The model are described for determining the optimum number of FAD's to 
Table 4 Material and size of deep sea rumpon in West Java

\begin{tabular}{|c|c|c|c|c|}
\hline No. & Component & Material & Size & Unit \\
\hline \multirow[t]{3}{*}{1.} & Buoy & & & \\
\hline & Raft buoy & Bamboo & $7 \mathrm{~m} \times(2 \mathrm{~m} ; 6 \mathrm{~m})$ & 1 \\
\hline & Extra buoy & Oil drum & $200 \mathrm{lt}$ & 1 \\
\hline \multirow[t]{8}{*}{2.} & Attractor & & & \\
\hline & Main attractor & Coconut leaves & 33.5 & 17 \\
\hline & Ting rope & Nylon & $16 \mathrm{~mm} \times 30 \mathrm{~cm}$ & 1 \\
\hline & Weight & Cement concrete & $20 \times 20 \times 22 \mathrm{~cm}$ & 1 \\
\hline & Shackle & Steel & $18 \mathrm{~mm}$ & 1 \\
\hline & Thimble & Steel & $16 \mathrm{~mm}$ & 2 \\
\hline & Snap & Steel & $10 \mathrm{~mm}$ & 1 \\
\hline & Ring & Steel & $16 \mathrm{~mm}$ & 1 \\
\hline \multirow[t]{10}{*}{3.} & Mooring line & & & \\
\hline & Wire rope & Steel & $16 \mathrm{~mm} \times 80 \mathrm{~m}$ & 1 \\
\hline & Line & PE & - & 1 \\
\hline & Shackle & Steel & $18 \mathrm{~mm}$ & 16 \\
\hline & Swivel & Steel & $16 \mathrm{~mm}$ & 4 \\
\hline & Thimble & Steel & $16 \mathrm{~mm}$ & 12 \\
\hline & Ring & Steel & $24 \mathrm{~mm}$ & 2 \\
\hline & Counter weight & Cement concrete & $20 \times 20 \times 22 \mathrm{~cm}$ & 1 \\
\hline & Ring & Steel & $16 \mathrm{~mm}$ & 4 \\
\hline & Chain & Steel & $8 \mathrm{~mm}$ & 4 \\
\hline \multirow[t]{5}{*}{4.} & Extra line & & & \\
\hline & Wire rope & Steel & $12 \mathrm{~mm} \times 7 \mathrm{~cm}$ & 1 \\
\hline & Shackle & Steel & $16 \mathrm{~mm}$ & 1 \\
\hline & & & $18 \mathrm{~mm}$ & 1 \\
\hline & Clamps & Steel & $12 \mathrm{~mm}$ & 6 \\
\hline 5. & Sinker & Oil drums filled with concrete cement & $200 \mathrm{~kg}$ & 3 \\
\hline
\end{tabular}

Source : Monintja et al. 1991

be deployed and the optimum number of vessels in a fishery. Hilborn and Medley reported that the number of FAD's for a single tuna purse seine vessel operating in $10,000 \mathrm{~km}^{2}$. Profits are maximized with about 40 FAD's, which corresponds to one FAD every $250 \mathrm{~km}^{2}$, or mean distance between FAD's of a $5.8 \mathrm{~km}$. Several researchers have been interested in studying the interaction between tuna or small pelagic fishes with FAD's in the sea with the Hilborn and Medley model (1989). Widodo et al. (1993) observed that the catches and profit of rumpon in Maluku waters depend on the number of FAD's for a single vessel pole and line operating in $7,769 \mathrm{~km}^{2}$. The profits are optimized with about 40 FAD's, which corresponds to one FAD per $200 \mathrm{~km}^{2}$, or mean distance between FAD's of 14 km (about 7.6 nautical miles). Luasunaung (1999) showed that catch and profit or rumpon in Tamini Teluk depend upon the number of FAD's for a single vessel soma pajeko operating in $695 \mathrm{~km}^{2}$. The profits are optimized with about 55 FAD's, which corresponds to one FAD every $13.7 \mathrm{~km}^{2}$, or mean distance between FAD's of $3.7 \mathrm{~km}$ (about 2 nau-

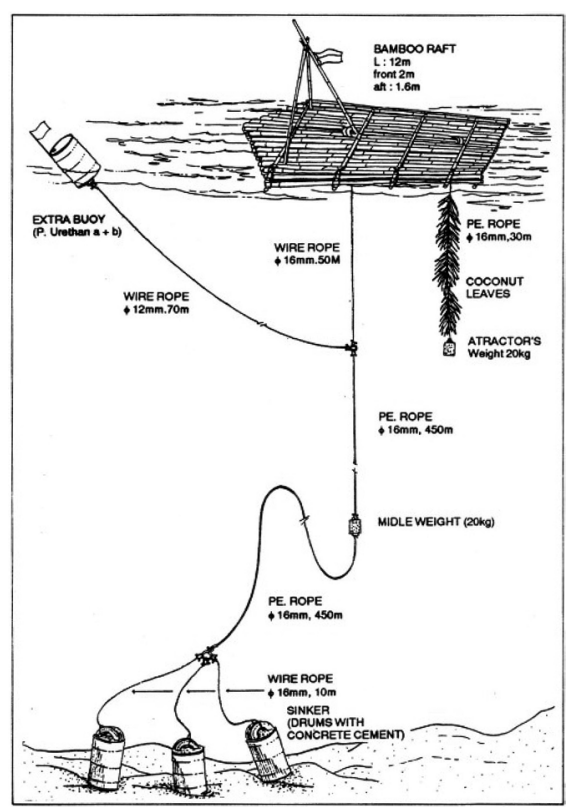

Fig. 3 Structure of deep sea rumpon in West Java (Monintja et al., 1991) 
Table 5 Material and size of shallow water rumpon in Banten

\begin{tabular}{|c|c|c|c|c|}
\hline No. & Component & Material & Size & Amount \\
\hline \multirow[t]{2}{*}{1.} & Buoy & & & \\
\hline & Raft & Bamboo & $\begin{array}{l}\Phi=0.1 \mathrm{~m}, \mathrm{~L}=15 \\
\mathrm{~m}\end{array}$ & $3-6$ bar \\
\hline 2. & Attractor & Coconut leaves & - & 25 sheet \\
\hline 3. & Mooring line & Polyethylene & $\begin{array}{l}\Phi=18 \mathrm{~mm}, \mathrm{~L}=63 \\
\mathrm{~m}\end{array}$ & - \\
\hline 4. & Bottom sinker & Mountain's stone & $50 \mathrm{~kg} / \mathrm{pc}$ & $2 \mathrm{pc}$ \\
\hline \multirow[t]{2}{*}{$\begin{array}{l}\text { No. } \\
1 .\end{array}$} & $\begin{array}{l}\text { Component } \\
\text { Buoy }\end{array}$ & Material & Size & Amount \\
\hline & Raft & Bamboo & $\begin{array}{l}\Phi=0.1 \mathrm{~m}, \mathrm{~L}=15 \\
\mathrm{~m}\end{array}$ & $3-6$ bar \\
\hline 2. & Attractor & Coconut leaves & - & 25 sheet \\
\hline 3. & Mooring line & Polyethylene & $\begin{array}{l}\Phi=18 \mathrm{~mm}, \mathrm{~L}=63 \\
\mathrm{~m}\end{array}$ & - \\
\hline 4. & Bottom sinker & Mountain's stone & $50 \mathrm{~kg} / \mathrm{pc}$ & $2 \mathrm{pc}$ \\
\hline
\end{tabular}

Source : Yusfiandayani 2004

tical miles). Yusfiandayani (2004) observed that the the optimum number of rumpon in Pasauran waters is 4 units, for the water area of $115.4 \mathrm{~km}^{2}$, and the mean distance of each rumpon is $5 \mathrm{~km}$ (about 3 nautical miles). The 4 units rumpon in Pasauran waters could render 154.4 ton of total catch/year with a profit of 38.2 million rupiah/year.

Species composition and size of fishes aggregating around the rumpons are skipjack tuna, clupeids and carangids in the waters off Sorong and Bacan Island. Examination on skipjack caught around rumpon in Bacan waters showed four features: 1) the size of fish does not differ significantly; 2) amount of catch increased as the fishing operation approached the rumpon; 3) amount of catch decreased from a peak in the early morning toward afternoon and 4) occurrence of fish schools for efficient operation delayed with distance from rumpon. The fishing operated most actively between $07.00 \mathrm{AM}$ to $08.00 \mathrm{AM}$ in the zone within $500 \mathrm{~m}$ from rumpon, between 08.00 AM to $09.00 \mathrm{AM}$ in the zone from $500 \mathrm{~m}$ to $1,000 \mathrm{~m}$, between 10.00 AM to $11.00 \mathrm{AM}$ in the zone from $1,000 \mathrm{~m}$ to 5,000 $\mathrm{m}$ and between $13.00 \mathrm{PM}$ to $14.00 \mathrm{PM}$ in the waters outside 5,000 $\mathrm{m}$ from rumpon (Monintja 1993).

Yusfiandayani (2004) observed that Cocos nucifera leaves are the best attractor material based on the thickness of cuticle, thickness of epidermis, density of periphyton, and number of fish species in all seasons. Further, the Gonado Somato Index (GSI) of small pelagic fish were caught around rumpon are GSI I 4\%, GSI II 33\% and GSI

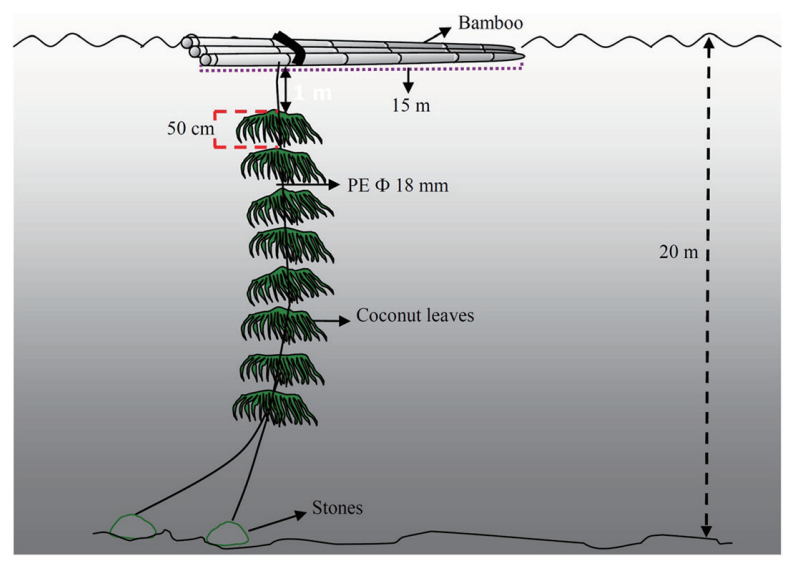

Fig. 4 Structure of shallow water rumpon in Banten (Yusfiandayani 2004)

III 35\%. This result indicated that the small pelagic fish caught around rumpons are 'immature fish' and could cause recruitment overfishing. The periphytons in the attractors were also found in the stomach content of 6 small pelagic fish species around rumpon. The rumpon fisheries in Pasauran have not met with the criteria of the Code of Conduct for Responsible Fisheries. The GSI of small pelagic fish were observed around rumpon indicated that the rumpon could cause recruitment overfishing. Rationalization of the existing 45 to 4 units rumpon in Pasauran waters is recommended to ensure the sustainability of the fisheries.

The Shimamaki study (Polovina and Sakai 1989) could 


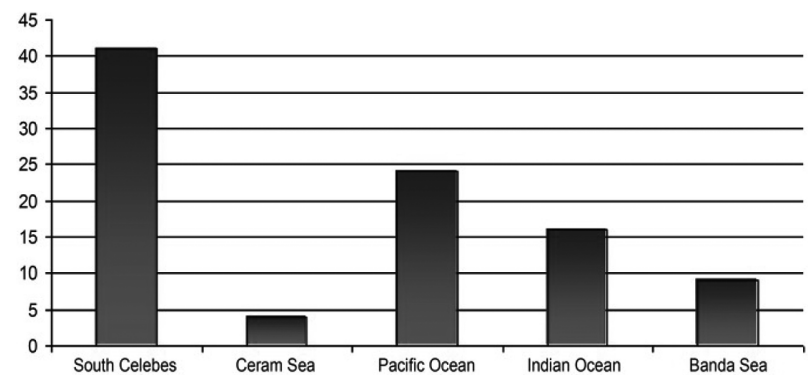

Fig. 5 Number of deep sea and shallow water rumpon in Indonesia

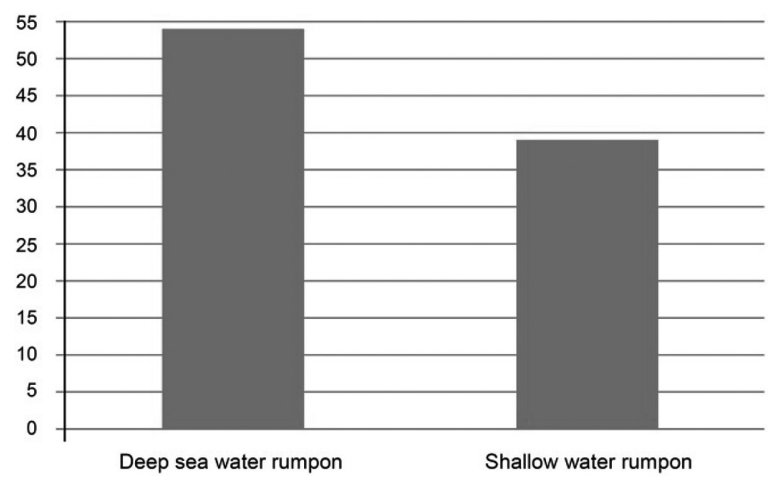

Fig. 6 Number of licensed deep sea and shallow water rumpon in Indonesia

not identify any biological impacts from the redistribution of exploitable biomass, but there were potentials impacts. Because the density of the exploitable biomass per-area of habitat had been reduced, growth and also natural mortality of the stock may have been impacted as well. However, the greatest impact may be a reduction in exploitable biomass if fishing at the artificial habitat is not restricted. The sitting of artificial habitat usually allows fishes to be more accessible causing an increase in fishing effort and resulting in higher fish mortality. An increase in fishing mortality will decrease the exploitable biomass in the area exploited. Whether the decrease in exploitable biomass results in lower future catches or recruitment to the fishery either locally or in an adjacent region depends on the stock dynamics. If the stock is migratory, then heavy fishing mortality in one region will result in lower levels of exploitable biomass in adjacent regions. If there is a strong regional stock recruitment relationship, then heavy local fishing mortality could reduce future recruitment.

FAO technical guidelines for responsible fisheries
(FAO 1996) pointed out that: fish aggregating technology should be further developed to improve the performance of anchored and drifting devices; the management system concerning FADs should determine the responsibility of the competent authority and the users for minimum design standards, operation and maintenance of FADs; the competent authority should also establish a system of approval for the deployment of FADs and maintain a record of the owner; the competent authority should ensure that the authorization to fish at FADs includes details of the fishing methods to be used as well as a requirement for reporting catches, FADs whether drifting or anchored, should means to identify their position by day and by night and the component authority should also establish a system for reporting lost FADs and their retrieval which are considered to be dangerous for navigation.

Based on the above guidelines, a comprehensive management program is ought to be established for the FAD operation. Vision, mission, objectives, target and management strategies on FAD are needed to be formulated, covering: integrated processes, focusing the condition expected by the stakeholders, what to be achieved, how much to be produced, what action to be done, how to achieve, should be discussed together including the stakeholders (not only by the government). Issues to be solved concerning the FAD management could be: the lack of data and information; indication of over capacity and overfishing; decrease of fishing business performance; conflicts; habitat destructions; threats on biodiversity; IUU fishing; by catch; discards; lack of law and regulations; law enforcement problems, etc. Management measures and detailed action to be applied, could include: FAD fishing ground zoning, fishing season, type and material of FAD to be allowed, number of FAD to be licensed, distance among FADs, number and type of fishing gear and method to be allowed, business management, socio and cultural consideration.

\section{Conclusion}

- The FAD utilization has increased the effectiveness, efficiency and regularity of the fishing activities.

- Unmanaged FAD fisheries will result in overcapacity, overfishing and unsustainable fisheries. 
- Fisheries using FADs have to be optimally managed to assure its sustainability through research, consultation, planning, resource allocation, and law enforcement.

\section{References}

FAO (1996) Technical guidelines for responsible fisheries, FAO, United Nation

Gooding RM, Magnuson JJ (1967) Ecological Significance of A drifting Object to Pelagic Fishes. Pac Sci 21: 486-497

Gorontalo Municipality Fisheries Agency (1990) Fisheries Annual Report. 1989. (In Indonesian), p. 40

Greenblatt PR (1979) Associations of Tuna with Floatsams in The Eastern Tropical Pasific. Fishery Bull 77 (1): 147-155

Hilborn R, Medley P (1989) Tuna Purse Seine Fishing with Fish Aggregating Devices (FADs): Model of Tuna FADs Interaction. Canadian J Fish Aqu Sci 46: 28-32

Hunter JL, Mitchell CT (1968) Association of Fishes with Flotsam in the Offshore Waters of Central America. U. S. Fish Wildl Serv, Fishery Bull 66: 13-29

Hunter JR, Mitchell CT (1968) Field Experiments on the Attraction of Pelagic Fish to Floating Objects. J Cons Perm Int Explor Mer 31 (3): 427-434

Inoue M, Amano R, Iwasaki Y, Yamauti M (1968) Studies on environment alluring skipjack and other tunas II. On the driftwoods accompanied by skipjack and tunas. Bull. Japan Soc Sci Fish 34: 283-287

Luasunaung A (1999) Soma Pajeko Fisheries with Rumpon: The interaction between Decapterus macarellus and Rumpon in Molibagu waters, Tomini Bay. (In Indonesian, Eng. Abstract). Postgraduate School. Bogor Agricultural University, Bogor. (Unpublished).

Mathews CP, Monintja DR (1996) Assessment of the Role of foreign and Industrial Tuna Fishing in Indonesia's EEZ, Archipelagic and Territorial Waters. Report Central Research Institute for Fisheries Research, Jakarta.

Mathews CP, Monintja DR, Naamin N (1996) Studies of Indonesian Tuna Fisheries: Part 2. Changes in Yellowfin Abundance in The Gulf Of Tomini And North Sulawesi. In: Shomura RS, Majkowski J and Horman RF (Eds.). Scientific Papers from the Second FAO Expert Consultation on Interactions of Pasific Tuna Fisheries, 23-31 January 1995, Shimizu, Japan, pp. 298-305

Monintja DR (1976) Modernizing the traditional rumpon to increase fishermen's income. (In Indonesia). Documented papers proposed to Directorate General of Fisheries, Jakarta, p. 6

Monintja DR, Baskoro MS, Purbayanto A (1991) Design and construction of fish aggregation device for skipjack and tuna fishing in Southern Java waters. (In Indonesian, Eng. Abstract). Proceeding of National Seminar on Research of Department of Higher Education, Sawangan, Bogor. 2124 January 1991, pp. 395-409

Monintja DR (1993) Study on the Development of Rumpon as Fish Aggregating Devices (FADs). Maritek, Bull ITK, FPIK-IPB. 3 (2): 137

Nasution CH, Merta GS, Arifudin R (1986) Study on romping and their aspects in Mamuju waters to develop tuna fishery in South Celebes. J Mar Fisheries Res 37: 31-58

Padang Municipality Fisheries Agency (1988) Report on SFDP Project. (In Indonesian), p. 36

Polovina JJ, Sakai I (1989) Impacts of artificial reefs on fishery production in Shimamaki, Japan Bull Mar Sci 44 : 9971003

Reuter J (1938) Voorlopig mededeling omtrent het roempoen onderzoek. Mededeling no. 2B. Institut voor Zeevisscherij. Batavia, p. 4

Scott JM (1969) Tuna schooling terminology. Calif Fish Game 55 (2) : 136-140

South Celebes Fisheries Agency (1987) Rompong in Mamuju District. (In Indonesian), p. 9

Wickham AD, Watson JW, Ogren LH (1973) The efficiency of midwater artificial structures for attracting pelagic sport fish. Trans Amer Fish Soc 3: 563-572

Wickham AD, Russel GM (1974) An evaluation of midwater artificial structures for attracting coastal pelagic fishes. Fish Bull 72 (1): 181-191

Widodo J, Bachtiar Gdan Merta IGS (1993) Interaksi antara Tuna dan Rumpon sebagai Alat Bantu Pengumpul Ikan pada Perikanan Huhate (Pole and Line) di Perairan Maluku dan Irian Jaya. Prosiding Simposium Perikanan Indonesia I, Jakarta, pp. 353-359

Yusfiandayani R (2004) Study on the Aggregation Mechanism of Small Pelagic Fish around Rumpon and Its Fisheries of Development in Pasauran Waters, Province of Banten. (In Indonesian, Eng. Abstract). Postgraduate School. Bogor Agricultural University, Bogor. (Unpublished).

C Japanese Coral Reef Society 